\title{
EchoGéo
}

$10 \mid 2009$

La piraterie

\section{Piracy around the Horn of Africa}

\section{Joshua Ho}

\section{(2) OpenEdition}

Journals

Édition électronique

URL : https://journals.openedition.org/echogeo/11370

DOI : 10.4000/echogeo. 11370

ISSN : 1963-1197

\section{Éditeur}

Pôle de recherche pour l'organisation et la diffusion de l'information géographique (CNRS UMR 8586)

\section{Référence électronique}

Joshua Ho, «Piracy around the Horn of Africa », EchoGéo [En ligne], 10 | 2009, mis en ligne le 02 septembre 2009, consulté le 16 septembre 2021. URL : http://journals.openedition.org/echogeo/ 11370 ; DOI : https://doi.org/10.4000/echogeo.11370

Ce document a été généré automatiquement le 16 septembre 2021

EchoGéo est mis à disposition selon les termes de la licence Creative Commons Attribution - Pas d'Utilisation Commerciale - Pas de Modification 4.0 International (CC BY-NC-ND) 


\title{
Piracy around the Horn of Africa
}

\author{
Joshua Ho
}

\section{Résumé long}

2 Depuis 1991 et le départ de Siad Barre, la Somalie vit dans un profond chaos. En 2004, un gouvernement fédéral de transition a été mis en place avant d'être renversé par l'Union des tribunaux islamiques deux ans plus tard. Ces derniers ont dû à leur tour battre en retraite suite à l'arrivée des forces éthiopiennes qui ont réhabilité les autorités précédentes fin 2006. Depuis le départ de ces troupes, le désordre prend de l'ampleur.

3 Dans ce contexte, la piraterie explose. Déjà présente dans les années 80 puis en augmentation dans les années 90, elle a franchi un palier en 2008. Cette industrie intéresse non plus seulement les jeunes désœuvrés mais aussi les seigneurs de guerre, des chefs de clans et des fonctionnaires corrompus. Le lien avec les milices islamistes est plus difficile à établir avec certitude.

4 Pour mener à bien leurs opérations, les pirates sont lourdement armés, entre autres de lance-roquettes et d'AK-47. Ils opèrent à bord de vedettes rapides et depuis des bateaux-mères mouillants au large des côtes. Depuis quelques mois, les pirates se montrent de plus en plus ambitieux dans le choix de leurs cibles, comme l'illustrent les attaques contre le Faina, avec à son bord des chars, et contre le superpétrolier Sirius Star.

5 Ce regain de la piraterie pèse sur les armateurs. En plus du coût des assurances qui peut tripler chez certaines sociétés, le détour par le cap de Bonne espérance - pour éviter la zone à risque - nécessite davantage de carburant et de jours en mer. Aujourd'hui, les gestionnaires du canal de Suez s'inquiètent de cette source de revenues qui lui échappe en ne payant pas les péages.

6 Pour lutter en mer contre les pirates, les Etats-Unis ont pris l'initiative de mettre en place la Task Force 151. Cette coalition complète les opérations de l'OTAN dédiées à l'escorte des navires du programme alimentaire mondial. L'Europe, directement touchée par la piraterie, est également présente à travers l'opération Atalanta depuis 
décembre 2008. En parallèle, de nombreux navires patrouillent dans les eaux somaliennes sous leur propre pavillon.

7 Ces manœuvres aussi préventives que répressives sont juridiquement encadrées par quatre résolutions adoptées aux Nations unies en 2008. Ces dispositions offrent plus de flexibilité avec le droit de la mer et invitent à la coopération régionale. En sus, des réunions se sont tenues au Caire, à Nairobi ainsi qu'à Djibouti début 2009. Cette dernière conférence a donné lieu à l'adoption d'un code de conduite régional.

8 Dans le futur, des mesures devront être prises pour augmenter le nombre de navires sur place et surtout les modes de communication. Par ailleurs, il faudra s'attacher à mener davantage d'enquêtes à terre ainsi qu'à s'assurer des poursuites judiciaires, voire des emprisonnements. De plus, les marins sont eux aussi invités à prendre plus de mesures à bord de leurs navires. Surtout, le comportement des pétroliers et pêcheurs au large doit être irréprochable pour calmer les ardeurs des Somaliens.

Le contexte national reste déterminant et exige une solution rapide. Aussi les prochains efforts du nouveau président somalien devront-ils être suivis avec grande attention

\section{Background}

10 Somalia has been without an operational government since 1991 when the country's leader and a U.S. ally, Muhammad Siad Barre, was overthrown. Warlords have held sway in the urban centres for over a decade despite no fewer than 14 initiatives to create a central government. The country is poor and children starve and people kill one another in the streets of Mogadishu. Large numbers of the populace have turned to piracy.

11 Somalia's current Transitional Federal Government (TFG), established in 2004 and backed by the United Nations, the United States, and the regional Intergovernmental Authority on Development, has limited capacity to enforce rule of law throughout the country. It was based originally in Nairobi, Kenya but in mid-2005 moved to the Somali town of Baidoa, not to Mogadishu, the capital of Somalia, which has been dominated by Islamists.

When the Union of Islamic Courts (UIC) came to power in mid-2006, piracy in Somalia dropped to zero. This is because the UIC announced that they would punish those engaged in piracy according to Sharia law. For, example, when pirates struck the UAE cargo ship MV Veesham I, the UIC in response set to sea in small boats, recaptured the vessel and rescued the crew after a gun battle with the pirates. However, in December 2006, Ethiopian troops expelled the Islamist forces from Mogadishu and re-established the TFG.

The Somali TFG government continues to battle Islamic and other militias with the fighting concentrated in the capital, Mogadishu. Ethiopian forces supported the TFG prior to their withdrawal from Somalia on 13 January $2009^{1}$ as required under a recent cease-fire deal ${ }^{2}$ and in accordance with the Djibouti Agreement. ${ }^{3}$

14 After the withdrawal of Ethiopian troops, instability continued. The weak transitional government, the anti-Islamist warlords, the anti-government clan militias and Islamic groups, some of whom have links to Al-Qaeda elements, notably the Al Shabab, which has been declared a terrorist organisation by the U.S. in March 2008 and which is behind terrorist attacks on Ethiopia and U.S. interests in the region, struggled for 
power. To complicate matters, the TFG has no control over Puntland, which declared itself a semi-autonomous state in 1998 and is currently the base of piracy. Somaliland, which declared independence in 1991 after the overthrow of the Siad Barre regime, is also not part of the TFG.

\section{Causes of Piracy}

15 Piracy around Somalia started in the 1980s but accelerated after the fall of the Somalian government in the early 1990s. Originally the pirates claimed they were aiming to stop the rampant illegal fishing and dumping of toxic waste that continues to this day off the Somali coast. ${ }^{4}$ After the fall of the Somali government, piracy started to flourish especially when shipping companies started paying ransoms, initially in the tens of thousands of dollars range, rising to hundreds of thousands, and which now amount to millions. The pirates are young Somalis from poor communities in mainly the Puntland region so far. The majority of attacks have occurred off the Puntland region of Somalia, near the town of Eyl and in the Mudug region.

The Gulf of Aden is a transit point for the 20,000 ships a year that use the Suez Canal. ${ }^{5}$ According to the International Maritime Bureau 2008 Annual Report, ${ }^{6}$ more than 111 ships have been attacked in 2008 as compared to 44 in 2007.92 of the attacks were in the Gulf of Aden with 19 attacks off Somalia. There were 42 successful hijacks in 2008 as compared to 13 in 2007. As of 31 December 2008, there were 13 vessels with 242 crew members being held hostage for ransom on the East Coast of Somalia. Ransom demanded ranges from US $\$ 500,000$ to US $\$ 2,000,000$ and have escalated towards the end of 2008. Most captured ships are not released for less than US $\$ 10,000$. So far ransoms that have been accrued have amounted to between US $\$ 18$ million to US $\$ 30$ million in 2008, according to a report by Chatham House in October. ${ }^{7}$ Kenya's foreign minister has, however, put a higher amount to the ransoms paid and claims that more than US $\$ 150$ million in ransoms have been paid in $2008 .{ }^{8}$ The ransoms are usually negotiated directly between the ship owner and the pirates, but sometimes a middle man is used.

As the pirates become more successful and more profitable, it attracted the attention of Somali clan warlords. Apparently, the pirates are able to operate across clan lines for mutual benefit and have opened new, lucrative, multi-clan franchises. Officials have been reported to be complicit as well and as such it may not be the case that the authorities in Puntland want to stop the piracy. There are reports of nefarious relationships between fishing companies, private security contractors and Somali government officials. Although the jails are full of criminals, there seems to be a lack of will to prosecute, or the inability to fully house all the criminals in their jails. Many people are now flocking to these pirate havens to be recruited and to participate in piracy which may overwhelm the ability of the local jurisdiction to cope and respond. ${ }^{9}$

Islamists have also been reported to help with bases from which the pirates operate and arms are reportedly being smuggled from Eritrea. ${ }^{10}$ However, it is unlikely that the terrorist group Al-Shabab is involved as they have said that ships belonging to Muslim countries should not be seized after pirates hijacked the Saudi supertanker, the Sirius Star. Islamist leaders have also stressed that piracy is a capital offence under Islam and condemned the surge in piracy in Somalia's waters. ${ }^{11}$ 


\section{Modus Operandi of Pirates}

19 The pirates are armed with RPG, AK-47 assault rifles, and larger calibre anti-aircraft machine guns and anti-tank missiles.The attacks are launched from small speed boats, or 20-foot fibreglass skiffs with high freeboards and one or two 85-150 HP outboard engines which enable them to achieve speeds of up to $23 \mathrm{knots}$. As the endurance of the skiffs is limited, they are launched from mother ships that resemble the fishing trawlers prevalent in the region, which they can blend in with. These mother ships have greater endurance and can stay out at sea for a longer period of time. The mother ships move around in the seas of the region looking for targets of opportunity and when a merchant ship comes into view, the skiffs attack as a pack. It has been said that there are at least two mother ships in operation, with two skiffs in tow each. However, the frequency of pirate attacks may suggest a greater number of mother ships in operation. ${ }^{12}$

Previously only fishing vessels and smaller cargo ships were hijacked, but now targets include chemical tankers, fishing vessels, small cargo ships, bulk carriers, luxury yachts, VLCCs and recently, even a container vessel, ${ }^{13}$ which has hitherto been thought to be safe from pirate attack due to the high speeds that it could attain. It would appear then that all ships are potential targets for piracy in the Gulf of Aden.

21 Two of the more high profile targets have included a Ukrainian vessel loaded with heavy weapons and a Saudi owned VLCC. The MV Faina, or "crown" in Russian, was a Ukrainian vessel loaded with rifles, heavy weapons and 33 Soviet made T-72 tanks that the pirates captured on 25 September 2008. The ship was initially thought to have been heading for Sudan or some other African country, possibly Kenya. The MV Faina was $\mathrm{n}$ surrounded by three warships from the Combined Task Force 150 during its hijack to prevent the ship's deadly cargo from ending up in the hands of Somalia's Islamic insurgents and other terrorists. ${ }^{14}$ The initial ransom demand was for US $\$ 35$ million ${ }^{15}$ but it was finally released for a reported sum of US\$3.2 million. ${ }^{16}$ The second high profile target was the Saudi owned MV Sirius Star, a Very Large Crude Carrier (VLCC) of 318,000 dead weight tonnes, and 330 metre length that was hijacked on the 15 November 2008 at a distance of 450 nautical miles southeast of Mombassa, Kenya. The ship carried 25 crew members, and 2 million barrels of oil worth US $\$ 100$ million. ${ }^{17}$ The ship was anchored off Haradheere and US $\$ 25$ million in ransom was demanded initially. . However, the ship was released on the 9 January 2009 after a much reduced ransom payment of US $\$ 3$ million was paid. ${ }^{18}$

\section{Consequences of Piracy}

One of the consequences of piracy is the increase in insurance rates for the shipping industry and the need to purchase additional insurance to cover the risk associated with transiting a piracy prone region. For example, insurance companies now offer "kidnap for ransom" policies to ships that move through the Suez Canal. One insurance company, the U.K. based Hiscox, prices the policy at US $\$ 15,000$ per trip through the Gulf of Aden and it is reported that business is humming. ${ }^{19}$ Also, because of the danger posed to shipping transiting the Gulf of Aden, insurance premiums have risen tenfold. 
For example, insurance companies have increased premiums for sending a cargo shipment through the Gulf of Aden to about US $\$ 9,000$ from US\$900 a year ago. ${ }^{20}$

As ships try to circumvent the Gulf of Aden by travelling south around the Cape of Good Hope, there is an increase in travel time with its attendant costs. This detour will add $4,000 \mathrm{~km}$, or 12 to 15 days, to a tanker's trip, at a cost of between US $\$ 20,000$ to US $\$ 30,000$ a day. ${ }^{21}$ A.P. Moeller-Maersk A/S, one of the world's largest ocean-shipping lines, and other companies have said they will re-route some of their vessels around the southern tip of Africa instead of traversing the gulf, despite the added distance, time, and fuel costs. This is because tankers are considered more vulnerable with their low hulls and slower speeds. ${ }^{22}$ Taiwan shipping company, TMT, meanwhile has also said that it would be re-routing 20 oil tankers via the Cape of Good Hope. TMT's fleet is regularly employed to ferry crude oil supplies to consumers in Europe and the United States. ${ }^{23}$ Following the hijack of the MV Sirius Star, Odfjell SE, a major Norwegian shipping group, announced on 18 November that it has ordered its tankers, numbering about 90, to sail around Africa rather than to use the Suez Canal. ${ }^{24}$ Already, the number of ships transiting the Suez Canal in January has fallen by $22 \%$ compared to the same month in 2008 and represents the lowest level passing through the waterway in five years. ${ }^{25}$ To be sure, the reduction in the number of ships transiting the Suez Canal is not solely the consequence of rampant piracy off the coast of Somalia but also due to the aggressive capacity cutting measures taken by ocean carriers to reverse losses as carriers will save on canal fees by sailing around the Cape of Good Hope.

\section{Naval Forces on Scene}

The force that has been on scene the longest is Combined Task Force 150 (CTF 150). CTF 150 is a U.S. led multinational coalition naval task force with logistics facilities in Djibouti established to monitor, inspect, board, and stop suspect shipping to pursue the War on Terrorism in the Horn of Africa (HOA) region. However, CTF 150 does not have an anti-piracy mandate. Countries presently contributing to CTF 150 include Canada, Denmark, France, Germany, Pakistan, the United Kingdom and the United States. Other nations who have participated include Australia, Italy, Netherlands, New Zealand, Portugal, Spain, Turkey and Japan, which is providing logistics support to the effort. ${ }^{26}$ Although anti-piracy operations are not within the mandate of CTF 150, some of its ships have been involved in anti-piracy operations on a case-by-case basis through individual national commitment rather than as part of a Task Force. The ships have participated, for example, since 2006 in the escort of ships used for the United Nations World Food Programme, transporting food from Mombassa, Kenya to Mogadishu. ${ }^{27}$ CTF 150, under the mandate of the United Nations Security Council Resolution 1816 in June 2008, established a Maritime Security Patrol Area (MSPA) on the 22 August 2008, which is a maritime corridor through the Gulf of Aden aimed at deterring attack and the hijacking of ships seeking safe passage through the zone. ${ }^{28}$ To address the limitations of CTF 150, a new Combined Task Force 151 was established on the 8 January 2009 to provide a U.S.-led command structure for ships in CTF 150 that are allowed to conduct anti-piracy operations, and to also allow for the inclusion of nations willing to participate in U.S. led anti-piracy operations, but who do not want to be involved in the anti-terrorism tasks of CTF $150 .{ }^{29}$ Singapore will be sending a Landing Ship Tank equipped with two helicopters and two hundred personnel for a three-month tour of 
duty with CTF $151 . .^{30}$ South Korea and Japan will also be sending ships to be part of CTF $151 .{ }^{31}$

On 24 October 2008, NATO deployed five warships from the Standing NATO Maritime Group 2 (SNMG2) to conduct anti-piracy duties off the coast of Somalia. The five warships were from Italy, Greece, Turkey, the United Kingdom, and Germany. Under the codename of Allied Provider, the five vessels provided close protection for World Food Programme (WFP) vessels and patrolled routes most susceptible to criminal acts against merchant vessels. ${ }^{32}$ Allied Provider was a temporary operation that was requested by the Secretary-General of the United Nations, Ban Ki-Moon, on 25 September 2008 and was replaced by the EU (European Union) mission Atlanta in December 2008. ${ }^{33}$

The EU's operation was limited to a period of one year, and will to protect vessels from pirate attacks off the coast of Somalia. ${ }^{34}$ The operation was codenamed Atlanta and the ships are based in Djibouti and Kenya. The EU naval force will take over the role of escorting United Nations World Food Programme vessels and also protect vulnerable vessels cruising off the Somali coast. The naval task force includes six warships and three surveillance planes from France, Spain and Greece. To avoid duplication of the tasks done by CTF 150 and allay U.S. concerns that the EU deployment will weaken EU commitment to CTF 150, the EU force will take over the patrols of the MSPA and thereby free up assets from CTF $150 . .^{35}$ Norway has indicated through the UN Security Council that it would be open to requests for technical assistance to strengthen national capacity in the region to combat piracy, and was ready to contribute to naval operations in the area in 2009. Sweden, pending parliamentary decision, had also announced its intention to contribute a navy unit to the EU led operation Atlanta, primarily in order to protect and escort WFP vessels. ${ }^{36}$

Besides the ships operating under EU auspices, CTF 150, CTF 151, or NATO, there have been ships deployed to the Gulf of Aden on independent national missions primarily to protect national shipping plying the routes and in response to previous attacks on their ships. Countries that have despatched naval ships to the region include Russia, ${ }^{37}$ India, ${ }^{38}$ China $^{39}$ and Malaysia. ${ }^{40}$

Japan sent a team of Coast Guard officials to visit Yemen and Oman in mid-December 08 to learn more about attacks in the Gulf of Aden, study security measures aimed at stopping them, and look at ways to support anti-piracy efforts. The Japanese Ship Owner's Association says that there were ten raids on Japanese-affiliated vessels in 2008. ${ }^{41}$ Japan has also decided to dispatch destroyers to the Gulf of Aden for the antipiracy mission. ${ }^{42}$

\section{International Measures Adopted}

There have been several actions taken so far through the adoption of United Nations Security Council Resolutions to address the problem of piracy around the Horn of Africa. Such actions intensified in 2008, especially in response to the increasing ransom demands which have escalated dramatically in dollar terms during the year.

The landmark resolution was the United Nations Security Council Resolution 1816 (2008) adopted unanimously on 2 June 08 that lasted for 6 months. The Resolution authorised countries to enter Somali territorial waters and use all necessary means to 
identify, deter, prevent, and repress acts of piracy and armed robbery at sea in a manner consistent with the provision of international law. Hence, the international force could board, search and seize suspect vessels and arrest the perpetrators in the territorial waters of Somalia. However, the Resolution required that the forces cooperate with Somalia's interim government and notify the UN Secretary General when proposing to conduct anti-piracy operations in Somalia's TTW. Somalia's interim government has given approval for foreign forces to operate in Somalia's territorial waters and has consented to UNSCR 1816.

Recognising that while physical enforcement action at sea is important, actions to curb financial flows of pirates and deal with possible organised criminal elements have to be addressed as well. As such, the United Nations Security Council adopted Resolution 1844 (2008) on 20 November 2008. The Resolution imposed sanctions on pirates, arms smugglers, and perpetrators of instability and people who prevent the distribution of humanitarian assistance to Somalia which included entities as well as individuals. The resolution directs that member States freeze the funds and financial assets of those suspected of such acts and deny them entry and transit rights. An arms embargo was to be enforced and the provision of military technical assistance and military training was to be banned. In addition, member States were to ensure that their own nationals did not collaborate with the people and entities identified to be targets of the sanction..$^{43}$

As the UNSC Resolution 1816 only had a six month validity period and expired on the 1 December 2008, the UN Security Council adopted Resolution 1846 (2008) on 2 December 2008 which would last for one year. The resolution was in essence a renewal of the mandate given in UNSC Resolution 1816 (2008). Resolution 1846 (2008) allows States and regional organisations cooperating with the Somali Transitional Federal Government (TFG) to enter Somalia's territorial waters and use all necessary means, such as deploying naval vessels and military aircraft, as well as seizing and disposing of boats, vessels, arms and related equipment used for piracy, to fight piracy and armed robbery at sea off the Somali coast, in accordance with relevant international law. ${ }^{44}$

The UN Security Council also recognised that to curb the piracy problem, there needs to be concerted action on land as well, which resulted in the adoption of the UNSC Resolution 1851 (2008) on 16 December 2008 that would last for one year. The resolution allows States and regional organisations cooperating in the fight against piracy and armed robbery at sea off the coast of Somalia to undertake all necessary measures appropriate in Somalia, to interdict those using Somali territory to plan, facilitate or undertake such acts. The Council also invited entities to conclude special agreements or arrangements with countries willing to take custody of pirates in order to embark law enforcement officials, known as "shipriders", from the latter countries to facilitate the investigation and prosecution of persons detained as a result of operations conducted under the resolution. The entities were also encouraged to establish an international cooperation mechanism to act as a common point of contact among them on all aspects of the anti-piracy operations. ${ }^{45}$

As a result of the UNSC Resolution 1851 (2008), a UN Contact Group has been formed that aims to provide the international community with the necessary mechanisms for coordination and cooperation to combat piracy off the coast of Somalia, in accordance with international law. ${ }^{46}$ The Contact Group had its inaugural meeting in New York on 14 January 2009 and it participation included more than 20 countries, together with the European Union, NATO, and the African Union. There were four functional groups 
under the Contact Group. The first group was led by the United Kingdom and was responsible for the Coordination of naval operations and information sharing. The second group was led by Denmark \& the United Nations Office on Drugs and Crime which would address the judicial aspects of piracy. The third group was led by the United States and was responsible for strengthening industry awareness and capabilities. The last and fourth group was led by Egypt and was responsible for strategic communications and public information. The Contact Group also called for the setting up of an East African counter-piracy coordination centre (CPCC). The Contact Group would report its findings to the UN Security Council.

Besides international responses, there has also been an attempt at creating a regional response to the situation. On 20 November 2008, the Red Sea coastal states in the Arab league had a consultative meeting in Cairo, Egypt to coordinate a common strategy against piracy in the Gulf of Aden and off the coast of Somalia. The meeting was held under the joint presidency of Yemen and Egypt. ${ }^{47}$ The countries that attended included Saudi Arabia, Yemen, Sudan, Jordan, Djibouti, and the Somalia Transitional Federal Government. The communiqué mentioned that Arab nations around the Red Sea were principally responsible for security there and any arrangement or operation therein required prior consultation with those States. The communiqué also recommended establishing joint mechanisms, joint training for coast guard forces, and welcomed international and regional support as well as the promotion of coordination, consultation and exchange of information through the establishment of a regional maritime centre in Yemen.

An International Conference on Piracy around Somalia was also held in Nairobi, Kenya on 11 December 2008 that was backed by the United Nations and attended by 145 delegates from 45 countries, including ministers and ambassadors. ${ }^{48}$ The conference concluded that support must be given to Somalia to secure its coastal waters for the recovery of the Somali fishing community and industry. This could be done through the establishment of an effective police and coastguard to provide adequate law enforcement capacity to deal with piracy, human trafficking, illegal fishing and dumping of toxic waste. The conference also recommended the establishment of a task force comprising representation from the UN, the international community and Somalia, to identify and investigate the issues at the local community level including local complaints with regard to economic and security concerns, the illegal exploitation of Somali maritime resources, human and arms trafficking and toxic waste dumping. The joint communiqué issued at the end of the two day meeting admitted that piracy cannot be effectively tackled in Somalia without the return of peace, stability and a functioning government. The communiqué also highlighted the importance of strengthening the capacity of the Somali national as well as regional authorities in combating the piracy menace, both to interdict pirates at sea, and to take effective legal action against pirates once returned to shore. To that end an amount of US $\$ 1.3$ million was provided to boost the criminal justice systems of Kenya, Djibouti, Yemen and Tanzania. Providing a broader agreement between coalition countries and coastal nations such as Kenya, Tanzania, Djibouti and Yemen was one of the main proposals on the agenda of the conference. As a result, Yemen will be establishing a regional centre for exchanging information on piracy and for mobilising material support to coordinate regional and international anti-piracy efforts. ${ }^{49}$ 
January 2009, 21 governments of the Western Indian Ocean and the Gulf of Aden adopted the Djibouti Code of Conduct Concerning the Repression of Piracy and Armed Robbery against ships in the Western Indian Ocean and the Gulf of Aden after a conference organised under the auspices of the International Maritime Organisation (IMO)..$^{50}$ Although the Code of Conduct ismodelled on the ReCAAP Agreement ${ }^{51}$, it covers more matters, but unlike ReCAAP, it is not a formal agreement. The purpose of the Code of Conduct is to repress piracy and armed robbery against ships by information sharing, with national focal points, interdicting ships suspected of engaging in piracy, ensuring apprehension and prosecution of pirates and adopting uniform criteria for the reporting of incidents. It also calls for multiple states with legitimate interests to liaise, coordinate and facilitate rescue, interdiction, investigation and prosecution. The Code also provides for "Ship Riders" or "Embarked Officers" to facilitate arrests in each others maritime zones. Each participant will review its national legislation to ensure there are adequate measures in place to criminalise piracy and armed robbery against ships, and adequate guidelines for the exercise of jurisdiction, conduct of investigation and the prosecution of alleged offenders. There are also provisions on the Exercise of Jurisdiction. For example, in the Exclusive Economic Zone (EEZ), it declares that the seizing State may waive its primary right to exercise jurisdiction and authorise any other Participant to exercise jurisdiction. In the Territorial Sea, it states that the offenders are subject to the jurisdiction of the coastal State, unless otherwise arranged by the affected Participants. The Code also retains limits to protect the flag States and coastal States by providing that nothing in the Code is intended to entitle a participant to undertake in the territory of another Participant the exercise of jurisdiction and performance of functions which are exclusively reserved for the authorities of that other Participant by its national law. Also, nothing in the Code is intended to affect in any way the rule of international law pertaining to the competence of State to exercise investigative and enforcement jurisdiction on board ships not flying their flag.

\section{Possible Future Actions}

Although many resolutions have been adopted and conferences held to address the issue of piracy and armed robbery in the Gulf of Aden, the immediate action that needs to be done is to get more countries to contribute ships as there only 19 in the area currently. The current number of ships is not sufficient to cover the large area of operations and it is estimated that up to 68 ships are required to adequately cover the area. The coastline of Somalia is $3,900 \mathrm{~km}$ long which affords the pirates many launching points to attack ships at sea. The additional ships will be required to protect the ships and tankers, locate mother ships or boats and apprehend the culprits. Besides urging more countries to dispatch ships to the region, greater effort must be made to integrate those already present on scene into an operation that is more coordinated in order to make better use of scarce resources and make the anti-piracy effort more effective. It is not clear how the different ships from the EU, CTF 151 and the independent ships from India, Russia, China and Malaysia communicate with each other. A unique opportunity is presenting itself for the forces present to institute some form of common communications protocol to share information and it would be a pity not to work at greater collaboration between the different forces present.

EchoGéo, 10 | 2009 

to arrest and prosecute the persons operating in the hide-outs. However, no international force is forthcoming due to previous failed UN peacekeeping operations undertaken in the country. A possible alternative is to learn from a chapter in history.In the $16^{\text {th }}$ and $17^{\text {th }}$ centuries, monarchs that were frustrated by Spain's dominance of the Caribbean commissioned privateers to harass the Spanish fleet. In similar vein, the international community may consider incentivising the local community to conduct policing action against the pirates. Besides actions in Somalia itself, many of the attacks also appear to originate from the Yemeni coast and from the Yemeni island of Suqutra (Socotra). It may be necessary to adopt new United Nations Security Council Resolutions allowing the international forces present to take similar action in Yemeni waters as is currently granted to them in Somali waters.

in order to prosecute pirates overseas, there must be legal regimes enacted to enable the foreign forces to do so. Although the UNSC Resolutions 1846 and 1851 allows foreign forces to operate in the EEZ and territorial waters off Somalia, they will still need the consent of the Transitional Federal Government of Somalia to do so. In addition, if pirates are captured, the nation that captured the pirates must have enacted national legislation to allow for the prosecution of the pirates apprehended, on the high seas or the EEZ in accordance with UNCLOS Article 101. In particular, bilateral agreements will need to be concluded with regional countries for prosecution if the pirates are not to be brought back home. For example, both the United States and the United Kingdom have bilateral agreements to transfer apprehended pirates to Kenya for prosecution. However, it this appears to be on a case-by-case basis and there may be a need for a more broad based agreement with other countries as well. Examination of the use of other kinds of international legislation to enable prosecution, such as the 1988 SUA Convention, should also be considered.

41 Fourthly, the shipping industry will need to take greater security measures onboard the ships. There have been examples of ships that have repelled pirate attacks through aggressive manoeuvring and the use of non-lethal weapons like the Long Range Accoustic Device (LRAD). The use of guards onboard could also be considered. However, shipowners will have to discuss with their P\&I clubs on whether having guards onboard, either private security or military, will invalidate their cover as there is a question of whether the shipowner is acting as a 'prudent uninsured' in doing so. This is because although war risk insurers cover crew members killed or injured in pirate incidents, guards are not considered part of the crew of the ship. There is a perception that with guards onboard, the threat escalates, with a higher likelihood of a claim. The counter argument is that the shipowners are acting prudently due to the heightened risk in the Gulf of Aden. ${ }^{52}$ There is also a case to be made for insurers to incentivise shipowners to install security devices onboard by offering a discount on insurance premiums for ships that have adequate security equipment installed, much in the same way that deductibles increase with more safety devices installed in a car.

Fifthly, some of the grievances expressed by the Somalis as reasons for piracy should be addressed. In particular, many of the pirates used to be fishermen who worked in the sea daily until foreign vessels started fishing illegally along the Somali coast, destroying their nets and firing upon them. There were even accusations of the dumping of toxic waste. To address some of these grievances, there should be an international response 
to curb illegal fishing is Somali waters and some of the naval forces present could be used to police illegal fishing as well.

However, it must be recognised that the root cause of piracy and armed robbery in and around Somalia is due to extreme poverty and the breakdown of law and order. Therefore, in the longer term, there is a need to stabilise and resolve the political situation in Somalia and in particular to negotiate a power sharing deal in Somalia between anti-Islamist warlords, the Islamic courts, and the weak transitional federal government. The Djibouti Agreement that was signed on 18 August 2008 between the Transitional Federal Government and the opposition Alliance for the Re-liberation of Somalia (ARS) to promote peace and stability in Somalia was intended to set the framework for a political settlement in the country. ${ }^{53}$ The Djibouti Agreement had a four-point action plan: the cessation of all acts of armed confrontation between the parties; the UN to deploy an international stabilisation force from countries that are friends of Somalia excluding neighbouring countries; the undertaking of all necessary measures to ensure unhindered humanitarian access and assistance to affected populations; and the establishment of a Joint Security Committee to follow up on the implementation of the security arrangements..$^{54}$ However, the main limitation to the Djibouti Agreement is that the ARS does not represent all the opposition groups in Somalia that are involved in the fighting. For example, Al Shabab is not part of the ARS. ${ }^{55} \mathrm{Al}$ Shabab has vowed to take over most parts of Somalia and has been largely successful in recapturing Mogadishu after the departure of Ethiopian troops. That the ARS does not represent all the parties in Somalia also highlights the urgency of sending in a UN sanctioned international stabilisation force to uphold law and order and boost the weak African Union force present.

Recently, the Somali President Sheikh Sharif Ahmed, a moderate Islamist, said that he would impose Islamic law, or Sharia law, in Somalia but clarified that he would not agree to a strict interpretation of the law. ${ }^{56} \mathrm{He}$ agreed to the implementation of Sharia law in order to halt fighting between Somali forces and the Islamic insurgents and has said that once a solid political solution to the conflict was found, he would ask the African Union contingent to leave. Already, more than 40,000 Somalis have returned to abandoned neighbourhoods in Mogadishu. The pragmatism shown by the Somali President seems to be the best hope yet for a new round of peace if he could broker an agreement between the Islamic insurgents and both the Puntland and Somaliland governments. If he is successful, there may not be a need to deploy an international peacekeeping force in Somalia.

\section{Conclusion}

The piracy and armed robbery that is occurring off the coast of Somalia and in the Gulf of Aden presents a special case to the international community because of the total breakdown of law and order within Somalia and the lack of capacity to secure their waters unlike piracy in other regions, like the Malacca Straits, for example. The special nature of the situation in Somalia and the Gulf of Aden has resulted in the adoption of unprecedented measures by the UN Security Council, such as authorisations for measures in the territorial sea and in Somalia itself. However, the Resolutions contain provisions designed to ensure the measures do not establish a precedent for other regions or change the fundamental principles on jurisdiction over ships. For example, 
fundamental principles that have not changed include the need for the consent of the flag state to board a ship outside of the territorial sea unless an incident of piracy is taking place, and the need for consent of the coastal State when exercising jurisdiction in its territorial waters.

Despite the actions taken to date, it would still be difficult to prosecute and convict the suspected "pirates" in many cases, especially for attacks within the territorial sea of Somalia. The 1988 SUA Convention could be used as a basis for jurisdiction, extradition, and prosecution. States in every region should ratify and implement all relevant conventions including the 1982 UNCLOS and the 1988 SUA Convention. In addition, there is an urgent need for common legislation on maritime offences, including piracy and armed robbery against ships as well as to update domestic legislation to make piracy an offence in the penal code.

In the longer term, there is a need to facilitate a political settlement to restore law and order and governance in Somalia. In that regard, the Djibouti Agreement appears to offer the best chance for a resolution. However, to back up the Agreement, the international community would need to allocate troops to an UN-backed stabilisation force that will allow the eventual government formed to restore some semblance of law and order in the poverty ravaged country. The current effort of the Somali President to incorporate the interests of the Islamic insurgents and the interest of the Transitional Federal Government and the ARS should also be supported. If he succeeds in establishing broad based support for his initiatives, there may not be a need for external intervention in Somalia and piracy itself may also return to more normal levels.

\section{NOTES}

1. Mohamed Amiin Adow, "Ethiopian troops begin Somali withdrawal", CNN.com, 13 January 2009. <Available online at http://edition.cnn.com/2009/WORLD/africa/01/13/ethiopia.somalia/ index.html>

2. "Somali PM: President can't fire me", CNN.com, 14 December 2008. <Available online at http:// edition.cnn.com/2008/WORLD/africa/12/14/somalia.politics/index.html>

3. "Somalia: Scholars Sceptical About Recent Djibouti Agreement", Shabelle Media Network (Mogadishu), 13 June 2008.

4. "Ecoterra Reports on the UN/Kenya Conference on Piracy", Buzzle.com, 15 December 2008. <Available online at http://www.buzzle.com/articles/ecoterra-reports-on-the-un-kenyaconference-on-piracy.html>

5. Bill Varner, "Chasing Pirates Onto Somali Territory Gets Approval From UN", Bloomberg.com, 16 December 2008. <Available online at http://www.bloomberg.com/apps/news? pid=20670001\&refer=home\&sid=aawFZI.VMc_o\&refer+home\#>

6. ICC International Maritime Bureau, Piracy and Armed Robbery Against Ships: Annual Report, 1 January - 31 December 2008 (London: ICC IMB, January 2009)

7. Teo Cheng Wee, "The pirate gulf; The Gulf of Aden accounts for a third of all reported piracy worldwide", The Straits Times, 14 December 2008. 
8. David McKenzie, “Arms ship's owners strike deal with pirates”, CNN.com, 30 November 2008. <Available online at http://www.edition.cnn.com/2008/WORLD/africa/11/30/pirates.ship.deal/ index.html>

9. Jeffrey Gettleman, "Somalia's Pirates Flourish in a Lawless Nation", The New York Times, 31 October 2008.

10. Martin Plaut, "Pirates 'working with Islamists”, BBC News, 19 November 2008. <Available online at http://news.bbc.co.uk/go/pr/fr/-/2/hi/in_depth/7737375.stm>

11. "Tensions grow as Islamist fighters pledge to attack Somali pirates", The Age, 25 November 2008. <Available online at http://www.theage.com/action/printArticle?id=300818>

12. B. Raman, "Rules of Engagement in Maritime Counter-Terrorism \& Counter-Piracy", South Asia Analysis Group International Terrorism Monitor Paper No. 69, 20 ovember 2008. <Available online at http://www.southasiaanalysis.org/papers30/paper2930.html>

13. "Navy patrols fail to deter Gulf of Aden hijacking", Lloyd's List, 23 ebruary 2009. <Available online at http://lloydslist.com/ll/news/navy-patrols-fail-to-deter-gulf-of-aden-hijacking/ 20017620772.htm>

14. Teo Cheng Wee, "The pirate gulf; The Gulf of Aden accounts for a third of all reported piracy worldwide", The Straits Times, 14 ecember 2008.

15. Nick Wadhams, "Pirates in Standoff Threaten Food Aid, Global Shipping", National Geographic News, 10 ctober 2008. <Available online at http://news.nationalgeographic.com/ news/2008/10/081010-somalia-pirates.html>

16. Sandra Jontz, "Civilian ship repurposed to help anti-piracy effort", Stars and Stripes, 10 ebruary 2009. <Available online at http://www.stripes.com/article.asp? section $=104 \&$ article $=60602>$

17. "Capture of tanker a new security dimension", The Straits Times, 19 ovember 2008.

18. "Pirates free Saudi tanker for US $\$ 3 m$ ", The Straits Times, 10 anuary 2009, p. 16.

19. Nick Wadhams, "Pirates in Standoff Threaten Food Aid, Global Shipping", National GeographicNews, 10 ctober 2008. <Available online at http://news.nationalgeographic.com/news/ 2008/10/081010-somalia-pirates.html>

20. Miles Costello, "Shipping insurance costs soar with piracy surge off Somalia", The Times, 11 september. <Available online at http://business.timesonline.co.uk/tol/business/ industry_sectors/banking_and_finance/article4727372.ece>

21. Shuli Sudderuddin and Debbie Yong, "It's a terrible time to be a seaman; the nature of piracy has changed vastly these past three years, becoming frighteningly violent", The Straits Times, 23 November 2008.

22. Paulo Prada and Alex Roth, "The Struggle to Bring Pirates to Justice", The Wall Street Journal Asia, 15 December 2008. <Available online at http://66.114.70.144/cgi-bin/terjem.rex? WSJ_The_Struggle_To_Bring_Pirates_To_Justice-81215001>

23. Daniel Wallis, "Steel ship grabbed in new pirate strike", The Australian, 26 November 2008. $<$ Available online at http://www.theaustralian.new.com.au/story/ $\underline{0,25197,24709037-12377,00 . h t m l>}$

24. B. Raman, "If Pirates Can Hijack an Oil Super-Tanker With Such Ease, So can Al Qaeda", South Asia Analysis Group International Terrorism Monitor Paper No. 468, 19 November 2008. <Available online at http://www.southasiaanalysis.org/papers30/paper2929.html>

25. The number of ships transiting the Suez Canal in January 2009 was recorded at 1,313 vessels. See "Suez transits down 22\% in January", ci-online, 4 March 2009. <Available online at http:// www.ci-online.co.uk/default.asp?URL=news/showNews.asp?News_ID=24329>

26. Jim Garamone and Petty Officer 2nd Class Corolla B, "Pakistani Admiral Takes Command of Regional Maritime Task Force", American Forces Press Service News Articles, 24 April 2006. <Available online at http://www.defenselink.mil/news/newsarticle.aspx?id=15376> 
27. Combined Forces Maritime Component Public Affairs, "Coalition Naval Assets Challenge Hijackers on South Korean Motor Vessel", NAVY.mil, 4 April 2006. <Available online at http:// www.news.navy.mil/search/display.asp?story_id=22991>

28. Commander, Combined Maritime Forces Public Affairs, "Combined Task Force 150 Thwarts Criminal Activities", United States Africa Command News Article, 29 September 2008. <Available online at http://www.africom.mil/getArticle.asp?art=2137>

29. "Multinational Task Force Targets Pirates", American Forces Press Service, 8 January 2009. <Available online at http://www.defenselink.mil/news/newsarticle.aspx?id=52586>

30. Jermyn Chow, "SAF in anti-piracy mission", The Straits Times, 13 February 2009. <Available online at http://www.straitstimes.com/print/Breaking\%2BNews/Singapore/Story/ STIStory_337766.html>

31. "S. Korea set to conclude legal process for sending navy ship to Somalia", The Korea Herald, 24 February 2009. <Available online at http://www.koreaherald.co.kr/NEWKHSITE/data/ html_dir/2009/02/23/200902230072.asp>

32. "Operation Allied Provider", North Atlantic Treaty Organisation Factsheet, 2 December 2008. $<$ Available online at http://www.nato.int/issues/allied-provider/081202-allied-providerfactsheet-en.pdf>

33. "Counter-piracy in the Gulf of Aden: Operation Allied Provider", North Atlantic Treaty Organisation News, 10 October 2008. <Available online at http://www.nato.int/issues/alliedprovider/index.html>

34. "EU to launch first anti-piracy operation", CNN.com, 8 December 2008. < Available online at http://edition.cnn.com/2008/WORLD/africa/12/08/pirates.somalia.warships> See also Nicholas Yong, "Nautica gives pirates the slip in Gulf of Aden", The Straits Times, 21 December 2008.

35. Bjoern H Seibert, "EU NAVFOR: Countering Piracy in Somali Waters", RUSI Commentary, 2008. <Available online at http://www.rusi.org/go.php? structureID=S433A7E512CD1D\&ref=C492691049A922

36. United Nations Security Council, "Security Council Authorises States to Use Land-Based Operations in Somalia, as part of fight against Piracy off Coast, Unanimously adopting 1851 (2008)", UNSC 9541, 16 December 2008. <Available online at http://www.un.org/News/Press/docs/ 2008/sc9541.doc.htm>

37. "Russia to fight piracy off Somalia coast", RIA Novosti, 23 September 2008. <Available online at http://en.rian.ru/russia/20080923/117048983.html>

38. "India to "step up piracy battle"'BBC News, 21 November 2008. <Available online at http:// news.bbc.co.uk/2/hi/south_asia/7741287.stm>. See also Keith Wallis, "Indian navy could boost Gulf of Aden patrols", Lloyd's List, 21 November 2008. <Available online at http:// epaper.lloydslist.com/ll/news/indian-navy-could-boost-gulf-of-aden-patrols/ 20017592796.htm;jsessionid=50E22033070CB0B04E1C9EA606250218>

39. "Chinese ships head for Somalia", The Straits Times, 27 December 2008, p. A20.

40. "Malaysia helicopter saves ship from Somali pirates", Reuters Africa, 1 January 2009. <Available online at http://africa.reuters.com/top/news/usnJOE50003R.html>

41. "Coast Guard to Investigate Piracy off Somalia", NHK World, 18 November 2008. <Available online at http://www.nhk.or.jp/daily/english/18_27.html>

42. "Defense chief to order antipiracy mission to Somalia in early March", Japan Today, 9 February 2009. <Available online at http://www.japantoday.com/category/national/view/ defense-chief-likely-to-order-antipiracy-mission-in-early-march>

43. S/RES/1844 (2008), United Nations Security Council Resolution 1844 (2008), 20 November 2008.

44. United Nations Security Council, "Security Council decides States, Regional Organisations may use 'All Necessary Means' to fight piracy off Somalia Coast for a 12-month period", UNSC 9514, 2 December 2008. <Available online at http://www.un.org/News/Press/docs/2008/ sc9514.doc.htm> 
45. United Nations Security Council, "Security Council Authorises States to Use Land-Based Operations in Somalia, as part of fight against Piracy off Coast, Unanimously adopting 1851 (2008)", UNSC 9541, 16 December 2008. <Available online at http://www.un.org/News/Press/docs/ 2008/sc9541.doc.htm>

46. United Nations Security Council, "Security Council Authorises States to Use Land-Based Operations in Somalia, as part of fight against Piracy off Coast, Unanimously adopting 1851 (2008)", UNSC 9541, 16 December 2008. <Available online at http://www.un.org/News/Press/docs/ 2008/sc9541.doc.htm>

47. United Nations Security Council, "Security Council Authorises States to Use Land-Based Operations in Somalia, as part of fight against Piracy off Coast, Unanimously adopting 1851 (2008)", UNSC 9541, 16 December 2008. <Available online at http://www.un.org/News/Press/docs/ 2008/sc9541.doc.htm>

48. "Ecoterra Reports on the UN/Kenya Conference on Piracy", Buzzle.com, 15 December 2008. $<$ Available online at http://www.buzzle.com/articles/ecoterra-reports-on-the-un-kenyaconference-on-piracy.html>

49. United Nations Security Council, "Security Council Authorises States to Use Land-Based Operations in Somalia, as part of fight against Piracy off Coast, Unanimously adopting 1851 (2008)", UNSC 9541, 16 December 2008. <Available online at http://www.un.org/News/Press/docs/ 2008/sc9541.doc.htm>

50. Code of Conduct Concerning the Repression of Piracy and Armed Robbery against Ships in the Western Indian Ocean and the Gulf of Aden, 29 January 2009. See also "High-level meeting in Djibouti adopts a Code of Conduct to repress acts of piracy and armed robbery against ships", IMO Briefing 03, 30 January 2009. <Available online at http://www.imo.org/About/mainframe.asp? topic_id=1773\&doc_id=10933>

51. The ReCAAP Agreement provides for the participating countries to share information about piracy incidents within their jurisdictions through appointed focal points to a ReCAAP Information Sharing Centre (ISC). The ReCAAP ISC broadcasts the incidents to all the other participating countries.

52. David Osler, "Armed guards on ships could raise liability issues", Lloyd's List, 12 December 2008. <Available online at http://www.lloydslist.com/ll/news/sector/index.htm? sectorCode=Piracy $>$

53. Robert Wood, Acting Deputy Spokesman, "Somalia, August 18 Djibouti Agreement", U.S. Department of State Press Statement, 21 August 2008. <Available online at http://www.state.gov/r/ $\mathrm{pa} / \mathrm{prs} / \mathrm{ps} / 2008 / \mathrm{aug} / 108787 . \mathrm{htm}>$

54. "Somalia: Scholars Sceptical About Recent Djibouti Agreement" Shabelle Media Network (Mogadishu), 13 June 2008. <Available online at http://allafrica.com/stories/printable/ 200806130285.html>

55. “Somalia: 'Djibouti Agreement Does Not Concern Us' - Al Shabab”, Garowe Online, 22 August 2008. <Available online at http://allafrica.com/stories/printable/200808250041.html>

56. "Somali president bends to rebel demand for sharia law", CNN.com, 28 February 2009. <Available online at http://edition.cnn.com/2009/WORLD/africa/02/28/somalia.sharia/ index.html> 


\section{RÉSUMÉS}

La piraterie au large de la Corne de l'Afrique a augmenté à un degré tel que la communauté internationale a décidé d'agir de concert pour sécuriser cette voie maritime. Néanmoins, si les efforts entrepris sont principalement ceux de la communauté internationale, les démarches régionales ne sont qu'à leur commencement. Dans le court terme, davantage d'initiatives devront être prises au niveau opérationnel, comme l'envoi de bateaux supplémentaires et la coordination des actions menées. Dans le plus long terme, il faudra s'attaquer aux racines de la piraterie et aux difficultés auxquelles doivent faire face les Somaliens. Il s'agit en particulier de restaurer l'état de droit en supportant les chefs de file modérés dans leur tentative de créer un gouvernement représentatif.

Piracy around the Horn of Africa has risen to a level serious enough for the international community to take concerted action to secure an international sea lane. However, the efforts so far have been initiated mainly by the international community while regional efforts are only just beginning. In the short term, more action will have to be taken at the operational level like dispatching more ships and integrating the operations of ships already deployed to the area. In the longer term, the root causes of piracy and the grievances of the Somali people have to be addressed. In particular, there is a need to restore law and order in Somalia by supporting moderate leaders in their attempts to create a representative government.

\section{INDEX}

Keywords : Gulf of Aden, Horn of Africa, piracy, Somalia, UN Contact Group, UNSC Resolution 1851 (2008).

Mots-clés : Golfe d'Aden, Corne de l'Afrique, Somalie, UN Contact Group, Résolution 1851 (2008) des Nations unies.

Thèmes : Sur le Champ - Sur le Terrain

\section{AUTEUR}

\section{JOSHUA HO}

Joshua Ho (ishhho@ntu.edu.sg / Joshua.h.ho@gmail.com) is a Senior Fellow and Coordinator of the Maritime Security Programme at the S. Rajaratnam School of International Studies (RSIS), Nanyang Technological University (NTU), Singapore.

Il a publié tout dernièrement :

- Ho, Joshua, 2009. Combating Piracy and Armed Robbery in Asia: The ReCAAP Information Sharing Centre (ISC). Marine Policy, Volume 33, Issue 2.

- Ho, Joshua, 2009. Enhancing Safety, Security and Environmental Protection of the Straits of Malacca and Singapore: The Cooperative Mechanism. Ocean Development \& International Law, Volume 40, Issue 2, pp. 233-247. 